\title{
Guidelines of the Intensive Model of Development of the Banking System of Russia and the Actual Problems of its Realization
}

\author{
Nadezhda Martynenko ${ }^{1} \&$ Svyatoslav Lyalkov ${ }^{1}$ \\ ${ }^{1}$ Department of Banks \& Bank Management, Financial University under the Government of the Russian \\ Federation, School of Management, Moscow, Russian Federation \\ Correspondence: N. Martynenko, Department of Banks \& Bank Management, Financial University under the \\ Government of the Russian Federation, Moscow, Russian Federation. Tel: 7-495-615-7275. E-mail: bibm@fa.ru
}

Received: March 11, 2015 Accepted: April 10, $2015 \quad$ Online Published: May 25, 2015

doi:10.5539/res.v7n10p9 URL: http://dx.doi.org/10.5539/res.v7n10p9

\begin{abstract}
The banking system being an economic system is in course of constant development. Its structural elements must work together to bring the best effect. The article explores the present status of the Russian banking system and discusses the targets of its ongoing reforms. Modernization of the banking system of Russia is regarded in the contexts of current situation, role of the government and other market participants, actual problems including sanctions. Interconnection is traced between ongoing and planned measures designed for the banking system modernization and the development of main areas of the Russian economy.
\end{abstract}

Keywords: banking system, targets of development of the banking sector, reforms and modernization of the banking systems, new banking technologies, liquidity, regulation

\section{Introduction}

The modern banking system of Russia is a properly developed, using the best standards and effectively working (Figure 1) complex of the credit institutions realizing the functions of accumulation and mobilization of temporarily unused money, credit, payment, securities brokerage and others.

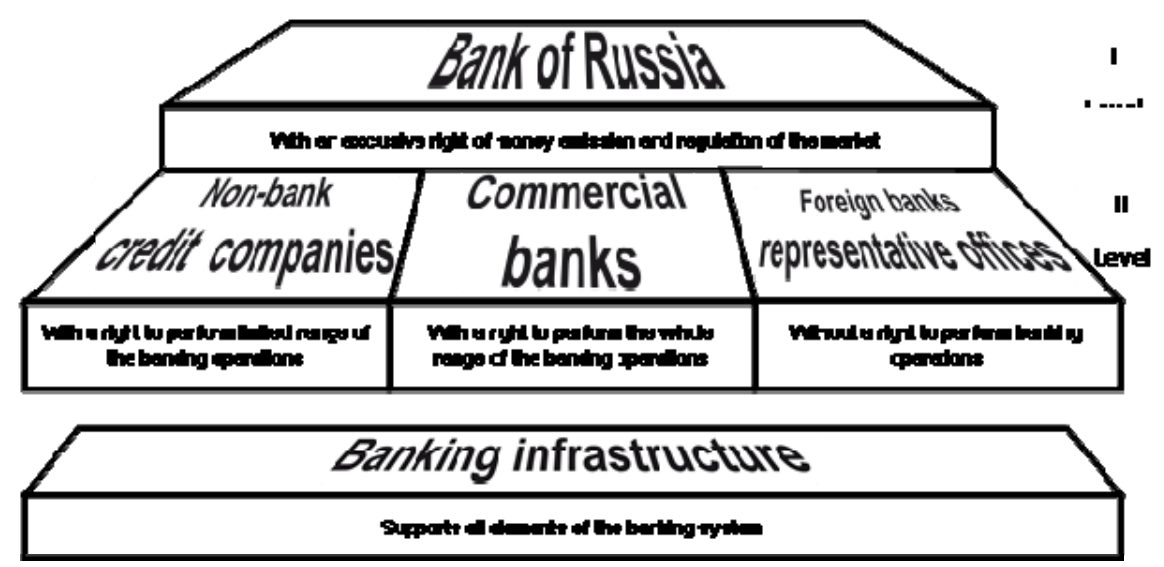

Figure 1. Banking system of Russian Federation

The quantity of the banks was formed on the evolution base and influenced by the market. The number of banks as at August 01, 2014 was 1057. Acting ones-877. 263 of them had the General license. (Sokolov \& Martynenko, 2014)

The banking system of Russia is in the constant and positively unreversable development process. Sometimes it develops according to the plans (acting one is a Strategy till 2015). On the different stages of its evolution it faces obstacles which correct some steps of the Strategy but never changes the key Strategy goals. This situation we can see nowadays. 
The Russian banking system faced an unprecedented situation because of an external factor in 2014. USA, EU and Japan imposed sanctions targeting biggest Russian banks (Sberbank, VTB, Gazprombank groups and Russian Agricultural bank). These financial institutions hold 57\% of the market and in fact are the most important and reliable part of the national banking system.(Bank of Russia, 2014) As they have got shrink of the funding base, we can speak about the tangible sanctions against whole banking sector of Russia. This factor inevitably reflects on the other sectors of the Russia's economy.

Also there is a strong specific internal factor. The policy of the Central bank of the Russian Federation which was designed to eliminate the unfair players from this market stressed the system long before the factor of sanctions appeared. During the period Sept. 30, 2013-Sept. 30, 201481 licenses were revoked, including 74 banks and 7 non-banking credit institutions. These figures are fourfold comparing the year before. The payments of the Deposit Insurance Agency grew from RUB 14.3 bln. in 2012 to RUB 145.5 bln in September 2014 (World Bank, 2014). 180 banking licenses were revoked as at the end of August 2014 all over the country. (Sokolov \& Martynenko, 2014)

Such challenges must be regarded in the process of update of the Strategy of the Russian banking sector but must not change the conceptual vector of its development and the further described main guidelines.

Mitigation of the negative external and internal factors, elimination of the existing problems of the banking system of Russia and encouraging of its qualitative transition are the main conditions of the intensive model of the system's development.

The guidelines of the Russian banking sector development (Figure 2) shows the main directions for the system modernization now and in the future.

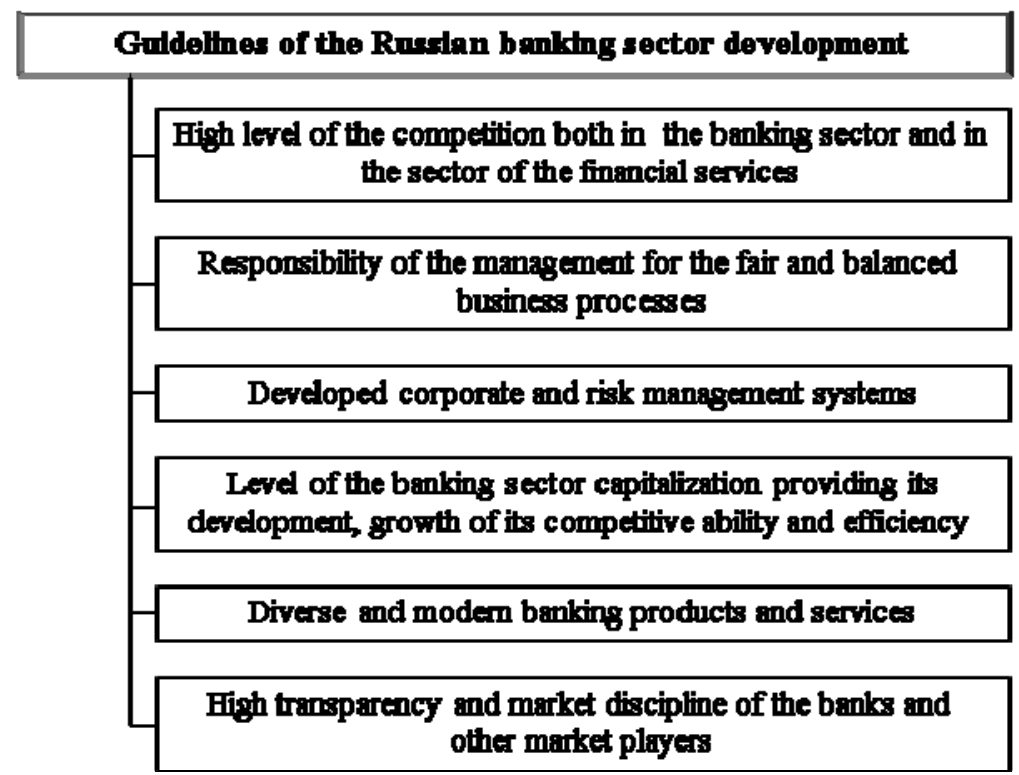

Figure 2. Guidelines of the Russian banking sector development

Russian Government and the Bank of Russia focused on the regulation streamlining promoting the reforms and modernization of the banking sector. It is supposed that such policy provides more efficient functioning of the system, its better input into the growth of economy. In should primarily improve the process of transformation of the potential financial resources into loans and investments.

Simultaneously the Government hopes that credit institutions will significantly widen their investments in the modern banking technologies and products.

The following main directions are planned for the Russian banking system reforms:

- Legislation improvement, emphasizing on the better business conditions, private property security, encouraging of the competition on the financial market;

- Modernization of the banking infrastructure on the basis of the best technologies, including the development of the systems of pledge registration, credit reference bureaus, payment and settlement system, central counterparty institution and other institutions and conditions; 
- Bank corporate governance and risk management quality growth;

- Banking regulations and supervision system upgrade;

- Providing the financial stability and soundness of the banking sector;

- Arrangement of conditions for competition in the banking sector and in the financial market;

- Growth of the competitiveness of the Russian financial institutions;

- Higher quality and accessibility of the banking services countrywide;

- Implementation of the modern banking and information technologies;

- Simplification and widening of the banking products for small business;

- Prevention of the illegal activities of the banks.

Therefor the following key measures are planned and being realized to implement the strategy of the banking sector development of Russia.

A significant state share is one of the characteristic features of the Russian banking sector ( $39 \%$ according to World Bank statistics) nowadays (Figure 3).

\section{Share of the state in the banking sector}

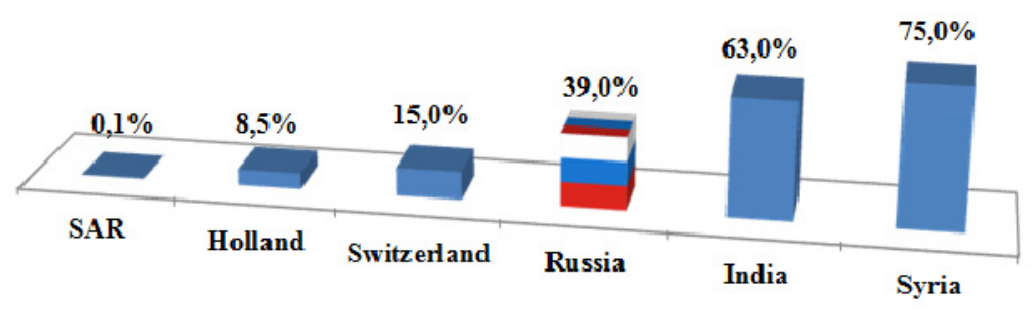

Figure 3. Share of the state in the banking sector

The Russian Government started to decrease its share in the banks. It is supposed to decrease this share but keep the control over Sberbank, Bank VTB and Russian Agricultural Bank.

As at January 2014 the Minister of Economic Development and Trade Alexey Ulyukaev declared reasonability of the approach that the share of Bank of Russia in equity of Sberbank and Bank VTB should be reduced to the control stock level in the midterm. For example, this share in VTB's equity should become $50 \%+1$ share in the end of 2016 (60.9\% now).

But a contradictory trend appeared in 2014 against the background of the problems in the financial markets inter alia as a result of the sanctions. The speed of privatization slows. The previous state privatization strategy forecasted zero share in VTB.

The process of conversion of the subordinated loans of the Central bank of Russian Federation to some Russian banks into their equity started. Even though this measure is necessary to keep the banking system stability in the present conditions it in fact means a step back to the deprivatization.

But the general guideline is kept unchanged. The nonbanking companies under the government's control (Russian Railways, Gazprom etc.) sell shares of non-core assets - credit institutions. The banks owned by regional and municipal authorities are supposed to be gradually privatized too.

The equal conditions in terms of the competitive landscape are kept for all credit institutions regardless of their scale and proprietary form, including state-owned banks.

The state actively participates in the development of the modern financial infrastructure including for the banks. We can regard as a bright example the preparations for the creation of the International Financial Center in Moscow. This Center should encourage integration of the Russian banking sector into the global markets. This project is on hold now because of the objective reasons but it is not cancelled.

The task of larger usage of the Russian ruble in the international payments and settlements is being solved. This direction got a strong shot in the arm after the Russian banks faced difficulties accessing funding in dollars and 
Euro. Cooperation in the currency issues is actively developing with the Asia region. For example the central banks of Russia and China signed an agreement for the currency swap-line for the amount of 150 billion yuans. That will allow payments in the bilateral trade without US dollars and will decrease the dependence on US currency.

\section{Banking System Infrastructure}

The main elements of the infrastructure that is being modernized are: national payment system, clearing institutions, exchanges etc. An unexpected (because there were no economic reasons for this) cut off of some Russian banks from the international payment systems' Visa and MasterCard services in the beginning of 2014 strongly encouraged the development of the Russian national system of the payment cards.

Despite of the sanctions of the USA, European Union and Japan the Government of Russia clings to the line of attraction of the foreign capital into the banking sector of the country. It understands the importance of the healthy competition and the state of the art technologies for the Russian banking market. Modern technologies, informatization of the sector, widening of the remote banking usage significantly increase the resource base of the credit institutions and allow making banks more effective.

New technologies are one of the main prerequisite for more ambitious target - the improvement of quality of the banking products and extension of their number. The modernization of the product line, decrease of the monetary, administrative, procedural, technical \& technological costs of the clients are the steps on the way towards this goal. In particular the rational minimization of the credit-application documents set, less time for decision-making in regard to the credit, more transparent banks are regarded as the waymarks.

There is a significant demand for the long term financing in Russia. Primarily such investments of the banks (also through PPP schemes) are needed for the infrastructure sector of the economy to provide its strategic development. Unfortunately depending on the outcome of the geopolitical situation "PPP in Russia has increasingly become a domestic market and may need to become permanently self-reliant", say experts. But the potential of this market is tremendous. The tenors of the projects exceed temporary political factors. The effect of the projects ensures the attractiveness of the Russian market. So the Russian banks try their best to strengthen mutually beneficial relationship with the foreign partners.

Some of the measures are to eliminate disproportion of the banking services accessibility generated by the territorial factor of such big country like Russia. The bank based on the network of offices of the Post of Russia Company is supposed to solve this problem. At the same time the regional network of the existing credit institutions will be developed. This will be achieved inter alia due to the cancellation of the territorial limitations for creation of the operational offices. The noncredit organizations will be encouraged to become more active in the regions with a lack of banking products offer.

The measures designed to protect creditors and make the borrowers more responsible are realized in the context of the development of the banking servicing of the nonfinancial sector. The novation into the pledge legislation of the end of 2013 became an important step on this way. The amendments in the Civil Code deal with the wide range of the pledge issues, in particular the pledge of the bank accounts was first time introduced in Russia.

The significant attention is paid to the development of the SME lending system, including indirectly through Vnesheconombank, the banks-partners system, leasing, factoring, microfinance companies and so on.

The role of securitization and syndicated loans grow. It is planned to implement practice of the contracts with the private persons - bank depositors without the right of early withdrawal of a deposit.

The mechanisms of mortgage loans refinancing is being widened inter alia by investing of the pension savings. The regulation for the maintenance of accounts for precious metals is being created.

The release of the banks from some uncharacteristic for them functions is being implemented among the measures designed for the reduction of the administrative load on the credit institutions. The following issues are discussed: renounce of the function of control of fulfillment by the companies of the rules of cash handling, cut of the list of bank management positions which must be approved by the Central Bank, unification of the requirements for the soundness of banks and some other.

Increased protection of the rights of consumers of banking services is expected to provide first of all through the refinement of legislation in the areas of consumer credit, right protection of the consumers of financial services and the improvement of the procedure of debt collection from the individuals debtors, as well as in the field of collection activity. Financial literacy, knowledge and skills of banking services usage play the significant role. 
An important aspect is also the improvement of banking regulation and supervision. The update of the powers of the Bank of Russia in accordance with the international requirements will continue in this direction. The focus will be on the refinement of mechanisms of the assessment of the credit institutions stability, on the authority to use the supervisory response, on the risks identification and assessment on the basis of the content and intensity of supervision based on the risk-oriented approach. The transfer in 2013 of functions of the Federal Service for the Financial Markets to the Bank of Russia became an essential factor that brought the regulation of the banking and stock markets to uniformity, synchronized these markets.

Among the key conditions for the progress in the banking sector are the growth of its capitalization, capital base improvement and capital adequacy maintenance to cover risks. International approaches - regulations developed by the Basel Committee on Banking Supervision regarding capital measurement and capital standards are being actively implementing in Russia. The requirements of international standard "Basel III" for capital of banks entered into force in Russia in January 2014. But objectively in the current situation when Russian banks artificially put in unequal competitive conditions, the introduction of separate elements of "Basel" may now be delayed.

Credit institutions will actively engage in the organization of cash circulation while the modernization of model of cash circulation will take place. Bank of Russia will delegate some of the functions to the commercial banks in this field. It is predicted that such redistribution of functions can cause narrow specialization for some banks working with cash. Bank of Russia says that it is quite possible that the creation in Russia of the National System of the payment cards in ten years may lead to the fact that banknotes and coins will largely go out of circulation.

The system of deposit insurance is being improved on the basis of the best foreign and domestic practices. Constant monitoring of the adequacy of the insurance coverage takes place. The feasibility of expanding of the range of protected subjects of the deposit insurance system is being examined. The adoption of the law which will increase the maximum size of the insured deposit to 1 million Rubles is expected in the coming months. Even 1.5 million level is discussed nowadays.

The approaches to the definition of the list of transactions subject to mandatory control and mechanisms of risk-based identification are being improved. The powers of supervisory institutions in the field of money laundering and terrorism financing prevention are being upgraded.

In order to develop the tools of the banking sector liquidity regulation Central Bank has planned and implements the optimization of refinancing mechanisms that will allow any financially stable Russian bank having proper provision to get a secured loan from the Bank of Russia.

Also a policy of expanding of the list of assets accepted as collateral, and of the improving of approaches to the REPO operations between the Central Bank and credit institutions within the refinancing system is being carried out. The first transactions using new instrument - a tripartite REPO took place in April 2013. The system of statutory ratios, terms and conditions of the deposit transactions with the Bank of Russia develops.

Because of compression of the resource base for the domestic banking sector in the summer and autumn 2014 the activity of Bank of Russia in the field of liquidity injections into the banking system became one of the most important factors for the market. As of mid-October 2014 the Ministry of Finance discussed currency deposit auctions - the newest tool to provide foreign currency liquidity and smoothing fluctuations of Ruble.

After solution of these problems the Russian banking sector will reach a new level of development. Domestic banking system on the main aspects will meet international standards.

All these transformations form the basis for to the banking sector assets to GDP ratio on January 1, 2016 to exceed $90 \%$, the ratio of total capital of banks to GDP will reach $14-15 \%$ instead of $10.6 \%$ at the beginning of 2011 , the ratio of loans to non-financial organizations and individuals to GDP will increase to $55-60 \%$ from $40.8 \%$ in early 2011.

The progress in this field is obvious and the goal seems attainable even in the current situation. On January 1, 2011, the ratio of assets of credit institutions to GDP was 76\%; at the beginning of 2014 it reached $86 \%$.

Russian banking sector already represents one of the most globalized industries against the background of the increasing integration of national economies into the world economy. And this integration is supposed to further deepen. This is an objective economic process. Effective continuation of its integration process affects not only the level of development of the national banking system, but also the quality of its services provision for the national and world economy, including the cost of resources, advanced technologies, etc. 
As existing sanctions against the Russian banks have the only political (not economic) basis they are temporary. It is abnormal and harmful both for Russian banks and for the world financial system as an independent economic mechanism that the bona fide banks are restricted from some basic operations.

\section{Conclusion}

So one of the main goals of the financial authorities and institutions in Russia and all over the world in the near future should become the recovering of the artificially broken by the sanctions long-term relationships between Russian banks and their foreign counterparties, first of all, credit institutions and investors. Such recovering is able to significantly affect both the efficiency of the banks in Russia and provide significant volume of attractive project for the foreign partners.

The important indicators of the banking system present development are the target-oriented and qualitative changes taking place in the nature and level of banking services, in competition, transparency and stability of the Russian banks. Improving the efficiency of banks as the elements of the economic system will impact on better performance of their customers through higher standards service. The strengthening of the role of banks in the innovation process for the real economy, for the growth of investment efficiency is expected.

All described guidelines and directions are strategic ones. Current changes in the market cannot and must not influence these guidelines.

Thus, the present and future development of the Russian banking system in the described key areas will lead to a significant transformation of the structure of the system enabling it to reach a new level of banking services for the economy, contributing to its growth and sustainable development.

\section{References}

A team of authors. (2014). In Y. A. Sokolov, \& N. N. Martynenko (Eds.), Money credit, banks: Textbook. Moscow: Urait Publishing house.

Anti-crisis aid will turn into shares'. (2014, June 30). Vedomosti newspaper.

Bank of Russia and People Bank of China signed an agreement for the currency swap. (n.d.). Retrieved from http://www.klerk.ru

Bank of Russia: Cash will go out of use in 10 years. (2014, July 2). RBC Information Agency.

Banking sector of the Russian Federation review. (2014, June). Central Bank of Russia.

Banking sector of the Russian Federation review. (2014, September). Central Bank of Russia.

Infrastructure Journal Global. (2014, June 20). Global PPP Market Review.

International Monetary Fund \& World Bank Report. (2013).

Interview of the President-Chairman of the Management Board of the Bank VTB Andrey Kostin. (2014, September 30). Izvestia newspaper.

Minfin will start level the Ruble fluctuations with the currency deposit auctions. (2014, October 15). Vedomosti newspaper.

Strategy of the development of the banking sector of the Russian Federation until 2015. (2015). Moscow, Government Press.

Ulyukaev considers reasonable to decrease the shares of Central bank in Sberbank and VTB in couple of years to the block shares'. (2014, January 27). Interfax news agency.

Where the banks leave. (2014, October 6). The results of the first year of market cleaning. Commersant newspaper.

World Bank. (2014, September 24). Russian economy report.

\section{Copyrights}

Copyright for this article is retained by the author(s), with first publication rights granted to the journal.

This is an open-access article distributed under the terms and conditions of the Creative Commons Attribution license (http://creativecommons.org/licenses/by/3.0/). 